\title{
Factors Affecting Students' Intention of Gamification for Learning Model in the Covid- 19 Pandemic Era at Indonesia: A Confirmatory Factor Analysis
}

\author{
Reny Nadlifatin ${ }^{1}$, Satria Fadil Persada ${ }^{2}$, Gita Widi Bhawika ${ }^{3}$, Gogor Arif \\ Handiwibowo ${ }^{4}$, Lissa Rosdiana Noer ${ }^{5}$, Bima Sakti Prayitno ${ }^{6}$, Mohammad \\ Fadhlur Rahman ${ }^{7}$
}

Institut Teknologi Sepuluh Nopember, Surabaya, Indonesia

( $\underline{\text { reny.nadlifatin@gmail.com }}{ }^{1, *}, \underline{\text { satriafp@gmail.com }}{ }^{2}$, gita@mmt.its.ac.id ${ }^{3}$, gogor@mmt.its.ac.id $^{4}$, sasarosdiana@gmail.com ${ }^{5}, \underline{\text { bimasaktip24@gmail.com }}{ }^{6}, \underline{\text { einzwein1@gmail.com }}{ }^{7}$ )

\begin{abstract}
The current study explores the measurement of gamification-based distance learning education on campus in the Covid-19 period. Thriving from the regular distance learning during the pandemic Covid-19, the element of interactive study and fun through games will help the students resolve their process of learning. The well famous Technology Acceptance Model, to include the perceived interactivity, is used as the measurement model. The assessment uses the confirmatory factor analysis, and nine hypotheses are stated. The research collects a total of 150 higher education students as the instrument of the sample. The data is analysed by a structural equation model to evaluate hypotheses testing. The result shows the suitability model in explaining the students' intention up to use gamification-based education. A total of seven out of nine hypotheses are accepted. AT presents the most dominant influence value to BI with the beta value of 0.87 . The overall model explains 76 percent of total intention in the measurement model. The theoretical and practical implications are further explained.
\end{abstract}

Keywords: Gamification, Campus, Distance Learning, Covid-19, TAM.

\section{INTRODUCTION}

Coronavirus pandemic, or best known as Covid-19, has hit the enormous impact on societies' activities from the beginning of the year 2020 [1]. Worldwide nations respond to the danger of the virus spreading in various actions such as physical distancing, lockdown, and isolation [2-4]. These actions are, without a doubt, forcing the business processes on many sectors to transform into digital-based activities [5]. Some of the transformations are bringing the dead end, while the others thrive successfully. The transformations also bring tight competition to the business model, where the innovation lead the key to sustain in the economic turbulence. The affected business models are such as officerelated activities, tourism, and education. The present research highlighted the educational point of view.
Education is one of the sectors which experienced the digitalization era way before the Covid-

19 arise [6]. However, Covid-19 forces all digitalization education in the form of distance learning. Distance usage learning will change the way professors and students to interact. From a technical perspective, the implementations of distance learning are in the form of synchronous and asynchronous [7]. The synchronous means that the way of communicating is two directions at the same time. The asynchronous is described as indirect communication between professors and students at different times. While the asynchronous is relatively monotonous, the synchronous approach requires more preparations and anticipations. The synchronous emphasize how the professors-students able to interact as similar to the offline classroom. The expectation of excellent two-way communications sometimes requires the Professor to think innovatively. Previous researches highlighted the use of Gamification as an innovative way to attract the students in the overall education process [8]. 
However, fewer researches explain on Gamification in the synchronous approach, especially during the pandemic period. The sudden transformation of distance learning in the pandemic period may bring another issue to its acceptance. The present research seeks to measure the students' intention to use Gamification based education. Specifically, the research uses the extent of a well famous Technology Acceptance Model (TAM) as the measurement model [9]. The present research outline is presented as follows. The following chapter 2 describes the relevant literature on Gamification and the TAM model. The development of hypotheses is also presented. Chapter 3 shows the detail of the research design. Chapter 4 reveals the insight from the data analysis. While chapter 5 concludes all the insight with the essential highlights.

\section{LITERATURE REVIEW}

The terminology of Gamification, in many kinds of research, can be best described as the use of game elements in non-gaming objects [8]. The ability to engage on users makes the Gamification famous in various industries [1013]. There are many application designs of Gamification, such as points, badges, leaderboards, and many others [14]. Gamification was validated by many researchers as helping in many processes such as educating, training, engaging, and learning [15-18]. The present research will measure the Gamification as an object in campus with gamification distance learning approach. Specifically, the use of TAM as behavior model is focused in this research.

Extending from the Theory of Reasoned Action, TAM model is designed as the model to capture human acceptance in technological usage [19]. The TAM model comprises of several essential elements such as perceived ease of use (PEU), perceived usefulness (PU), attitude (AT), and behavior intention (BI). PEU is best described as how the level of person feels about the particular thing that has less effort in operation. PU is known as the level of a person's impression about the particular thing that can help the task completion. The AT factor is the level of a person's affective on the particular thing, which projects a positive or negative result. BI is the representation level of a person's aim in conducting a particular behavior. The present research elaborates on the use of perceived interactivity (PI) as the antecedence factors, and it is presented in Figure 1. PI is the level of a person's impression about the particular thing that there are capabilities of being responsive in communication [20]. Many TAM kinds of research explore the suitability of the model in particular of education tools in learning [2123]. Although the focus of present research is on the students' acceptance of Gamification in the pandemic period, the characteristics of Gamification itself are much similar to the acceptance of gamification technology in the nonpandemic period. Thus, the present research hypothesizes as follow:

H1: PEU has a positive effect on the PU of students on Gamification

$\mathrm{H} 2$ : PEU has a positive effect on the AT of students on
Gamification

H3: PU has a positive effect on the AT of students on Gamification

H4: AT has a positive effect on the BI of students on Gamification

Several types of research discussed the existence of PI as one of the essential aspects in learning environments [20, 2426]. During the pandemic, all the transformations from offline to online are suddenly used. Therefore, the current research proposes the hypotheses below:

H5: PI has a positive effect on the PEU of students on Gamification

H6: PI has a positive effect on the PU of students on Gamification.

\section{METHODOLOGY}

The present research uses multiple cross-sectional periods, which were gathered in July 2020 through online form media. The sampling method in capturing the data is non-probability sampling with a purposive sampling approach. The appropriateness respondents in this research are the higher education students that they have experienced Gamification during the Covid-19 pandemic period. The scope of gamification media in this research are six common gamification platforms, namely Kahoot!, Quizlet, Socrative, AhaSlides, Gartic, and Quizizz. The target sampling numbers are the minimum number of questions times 5 , which are more than 100 . The questionnaire comprises two sections, in which the opening section grasps the respondents' profile. The profile contains the name, education degree, campus status, and types of gamification media used mostly. Most of the data types in section one are nominal. Section two asking the questions related to the measurement model. The measurement model is projected in a 5-point interval Likert Scale, ranging from "I strongly agree" to "I strongly disagree" as it can be seen on Table 1 . The research uses confirmatory factor analysis with structural equation model (SEM). The hypotheses are instrumented by questionnaire-based data collection in section 2. In this research, SEM reveals the measurement and structural model through several tests that must be conducted, such as reliability, construct validity, model fit, and hypotheses validation. Reliability is intended to make sure that the data are consistent. The test is conducted with Cronbach's $\alpha$, and composite reliability (reliability with factor loadings formula) approaches. The good minimum values of both reliability tests are 0.7 [27-29]. Construct validity in this research is described by their discriminant and convergent trends. Discriminant and convergent are used to measure whether the two constructs have relations in the construct (latent factor). Several recommendations use Average Variance Extracted (AVE) in the SEM researches, in which a minimum of 0.5 is suggested. [28, 30, 31]. Model fit tests in this research utilize several indices indicators such as the root mean square residual (RMR), root mean square 
error of approximation (RMSEA), incremental fit index (IFI), and comparative fit index (CFI). RMR calculates the square root of the gap between residual in covariance research sample and the covariance that is being measured. RMSEA estimates the fit of population data with the covariance matrix. IFI is a comparative approach to the chisquare score with the baseline model. CFI is a calculation on sample size in the formula of the $\chi 2$ model and $\chi 2$ null model. The minimum recommended values in various researches are $0.08 ; 0.08 ; 0.9 ; 0.9$, respectively [20,32-34]. The final analysis is hypotheses validation. The validation uses the beta value in every relationship with a significant p-value of 90 percent

Table 1. Construct of Latent Variable

\begin{tabular}{|l|l|}
\hline Indicators & Questions \\
\hline PI1 & $\begin{array}{l}\text { I felt that the Gamification media I use } \\
\text { gives the facility for two ways } \\
\text { communication }\end{array}$ \\
\hline PI2 & $\begin{array}{l}\text { I felt that the Gamification media I use } \\
\text { gives the two ways information }\end{array}$ \\
\hline PI3 & $\begin{array}{l}\text { I felt that the Gamification media I use } \\
\text { gives the two ways feedback }\end{array}$ \\
\hline PI4 & $\begin{array}{l}\text { I felt that the Gamification media I use } \\
\text { gives the two ways input }\end{array}$ \\
\hline PU1 & I felt that the Gamification media I use \\
\hline
\end{tabular}

\section{ANALYSIS AND DISCUSSION}

One hundred fifty respondents participated in this research, which comprises of 42 male and 108 female participants. The respondents are majorly in the bachelor program with 129 numbers, followed by 18 numbers in the master program, and three numbers of vocation associate degree. A total of 134 students are come from public universities, while 16 are from private universities. One hundred two respondents are answering the Kahoot usage, eight respondents use Quizlet, two respondents use Socrative, two respondents use AhaSlides, one respondent uses Gartic, and 35 respondents use Quizzizz. From the sampling data, the reliability and convergent validity are analyzed by using the factor loadings (FL), CR, Cronbach's $\alpha(\alpha)$, and AVE.

The minimum suggested values of SEM researches in the various area for FL, CR, $\alpha$, and AVE are 0.7, 0.7, 0.7, and 0.5 , respectively $[20,33,35-42]$. Table 2 shows the overall values, which are meet the minimum values. The next test is a model fit test, which is the RMR, RMSEA, IFI, and CFI. The present research produces 0.04; 0.08; 0.90 ; and 0.90 consecutively. Thus, the model in this research is fit enough in presenting the similarity with real conditions.

The last measurement in this research is the hypotheses validation. Based on the model result (see Figure 2), all the beta coefficients generate positive values. However, not all beta coefficients are significant enough. Table 3 reveals all the significant values developed by the overall model, where a total of five from six hypotheses are accepted. One hypothesis is rejected due to insignificant value. The squared multiple correlations of students' behavior intention in accepting the campus gamification for distance learning is predicted by 76 percent, which indicates that other factors outside this model might cause the rest of 24 percent value. This 76 percent values are relatively good compared to similar research in electronic education with SEM approaches $[20,33,34,43]$. 
Table 2. Significant Hypotheses

\begin{tabular}{|l|l|l|l|}
\hline No. & Hypotheses & Value & Status \\
\hline 1. & H1: PEU?PU & 0.432 & 0.005 \\
\hline 2. & H2: PEU?AT & 0.104 & 0.193 \\
\hline 3. & H3: PU ?AT & 0.777 & 0.004 \\
\hline 4. & H4: AT ? BI & 0.874 & 0.002 \\
\hline 5. & H5: PI ?PEU & 0.390 & 0.002 \\
\hline 6. & H6: PI ? PU & 0.421 & 0.001 \\
\hline
\end{tabular}

The influence between AT and BI (H4) is revealed to be the most substantial value of the overall model $(\beta \mathrm{AT}$ ? $\mathrm{BI}=0.874)$. The strongest value indicates that the students' have a positive favorable feeling towards the Gamification. This situation must be maintained and replicated to other similar distance learning. From the antecedence of AT factor, PU is depicted as a strong predictor of AT $(\beta \mathrm{PU}$ ? $\mathrm{AT}=0.777)$ compared with PEU $(\beta \mathrm{PEU}$ ? $\mathrm{AT}=0.104)$. It can be said that the students agree to see the Gamification as something useful in their education. On the contrary, there is no significant evidence of the easy use of Gamification. Perhaps, the way gamification displays that always changing contributed to the way the students feel about the difficulty. The way PI influence as the predictor to PEU is significant $(\beta \mathrm{PI}$ ? PEU= 0.390). Students tend to see the interactive in Gamification as an additional effort to learn. In brief, students are more likely to have a favorable feeling with the usefulness of Gamification, which is driven by the interactivity. Finally, ensuring the high value of AT to BI will increase the educational process based on Gamification.

\section{CONCLUSIONS}

The present research explores the measurement of students' intention to Gamification based education during the Covid-19 pandemic period. The seven out of nine hypotheses are having positive and significant results. The AT factor is revealed as the strongest predictor among the overall factors $(\beta \mathrm{AT}$ ? $\mathrm{BI}=0.874)$. Several suggestions, such as maintaining the AT influence as big as possible is prioritized. The educator should put the interactivity element as the primary concern in designing the lecture sessions. Several types of research limitations are highlighted. The first limitation is related to sampling, where most of the respondents are from the bachelor program, considering the balance proportion is suggested. The second limitation is from the model itself. Adding other factors such as infrastructure readiness or other factors may increase the percentage of squared multiple correlations of the BI factor, which helps the researchers and educators to understand the situation better.

\section{ACKNOWLEDGMENTS}

We would like to show the high appreciation to Institut Teknologi Sepuluh Nopember for giving the research funding with number $1584 / \mathrm{PKS} / \mathrm{ITS} / 2020$. The authors also express gratitude to all the stakeholders involved in this research.

\section{REFERENCES}

[1]. C. P. E. R. E. Novel, "The epidemiological characteristics of an outbreak of 2019 novel coronavirus diseases (COVID-19) in China," Zhonghua liu xing bing xue za zhi= Zhonghua liuxingbingxue zazhi, vol. 41, no. 2, pp. 145, 2020.

[2] D. K. Chu, E. A. Akl, S. Duda, K. Solo, S. Yaacoub, H. J. Schünemann, A. El-harakeh, A. Bognanni, T. Lotfi, and M. Loeb, "Physical distancing, face masks, and eye protection to prevent person-to-person transmission of SARSCoV-2 and COVID-19: a systematic review and meta-analysis," The Lancet, 2020.

[3] J. Hellewell, S. Abbott, A. Gimma, N. I. Bosse, C. I. Jarvis,T. W. Russell, J. D. Munday, A. J. Kucharski, W. J. Edmunds, and F. Sun, "Feasibility of controlling COVID-19 outbreaks by isolation of cases and contacts," The Lancet Global Health, 2020.

[4]. H. Lau, V. Khosrawipour, P. Kocbach, A. Mikolajczyk, J. Schubert, J. Bania, and T. Khosrawipour, "The positive impact of lockdown in Wuhan on containing the COVID-19 outbreak 
in China," Journal of travel medicine, vol. 27, no. 3, pp. taaa037, 2020.

[5]. Y. K. Dwivedi, D. L. Hughes, C. Coombs, I. Constantiou, Y. Duan, J. S. Edwards, B. Gupta, B. Lal, S. Misra, and P. Prashant, "Impact of COVID-19 pandemic on information management research and practice: Transforming education, work and life," International Journal of Information Management, pp. 102211, 2020.

[6]. S. Islam, and N. Jahan, "Digitalization and Education System: A Survey," International Journal of Computer Science and Information Security (IJCSIS), vol. 16, no. 1, pp. 70-73, 2018.

[7]. R. F. Branon, and C. Essex, "Synchronous and asynchronous communication tools in distance education," TechTrends, vol. 45, no. 1, pp. 36, 2001.

[8]. D. Dicheva, C. Dichev, G. Agre, and G. Angelova, "Gamification in education: A systematic mapping study," Journal of Educational Technology \& Society, vol. 18, no. 3, 2015.

[9]. F. D. Davis, "Perceived usefulness, perceived ease of use, and user acceptance of information technology," MIS quarterly, pp. 319-340, 1989.

[10]. S. Doherty, E. Palmer, and L. Strater, "Gamification: Current research and applications." pp. 2096-2099.

[11]. N. I. Mohd, K. N. Ali, S. Bandi, and F. Ismail, "Exploring gamification approach in hazard identification training for Malaysian construction industry," International Journal of Built Environment and Sustainability, vol. 6, no. 1, pp. 51-57, 2019.

[12]. C. Wolf, S. Bott, I. Hernandez, and L. Grieve, "Teaching about the health care industry through gamification," American journal of pharmaceutical education, vol. 82, no. 4, 2018.

[13]. F. Xu, J. Weber, and D. Buhalis, "Gamification in tourism," Information and communication technologies in tourism 2014, pp. 525-537: Springer, 2013.

[14]. Y.-k. Chou, Actionable gamification: Beyond points, badges, and leaderboards: Packt Publishing Ltd, 2019.

[15]. K. M. Kapp, The gamification of learning and instruction: game-based methods and strategies for training and education: John Wiley \& Sons, 2012.

[16] .J. Looyestyn, J. Kernot, K. Boshoff, J. Ryan, S. Edney, and C. Maher, "Does gamification increase engagement with online programs? A systematic review," PloS one, vol. 12 , no. 3 , pp. e0173403, 2017.

[17]. C. I. Muntean, "Raising engagement in e-learning through gamification." pp. 323-329.
[18]. K. Robson, K. Plangger, J. H. Kietzmann, I. McCarthy, and L. Pitt, "Game on: Engaging customers and employees through gamification," Business horizons, vol. 59, no. 1, pp. 29-36, 2016.

[19]. F. D. Davis, R. P. Bagozzi, and P. R. Warshaw, "User acceptance of computer technology: a comparison of two theoretical models," Management science, vol. 35, no. 8, pp. 9821003, 1989.

[20]. S.-C. Lin, S. F. Persada, and R. Nadlifatin, "Astudy of student behavior in accepting the Blackboard Learning System: A Technology Acceptance Model (TAM) approach." pp. 457462.

[21]. S. Alharbi, and S. Drew, "Using the technology acceptance model in understanding academics' behavioural intention to use learning management systems," International Journal of Advanced Computer Science and Applications, vol. 5, no. 1, pp. 143-155, 2014.

[22]. T. Farahat, "Applying the technology acceptance model to online learning in the Egyptian universities," Procedia-Social and Behavioral Sciences, vol. 64, pp. 95-104, 2012.

[23]. S. Y. Park, "An analysis of the technology acceptance model in understanding university students' behavioral intention to use e-learning," Journal of Educational Technology \& Society, vol. 12, no. 3, pp. 150-162, 2009.

[24]. J. L. Lear, C. Ansorge, and A. Steckelberg, "Interactivity/community process model for the online education environment," Journal of online learning and teaching, vol. 6, no. 1, pp. 71-77, 2010.

[25]. J. Y. Park, "Student interactivity and teacher participation: An application of legitimate peripheral participation in higher education online learning environments," Technology, Pedagogy and Education, vol. 24, no. 3, pp. 389-406, 2015.

[26]. J.-n. Sun, and Y.-c. Hsu, "Effect of interactivity on learner perceptions in Web-based instruction," Computers in Human Behavior, vol. 29, no. 1, pp. 171-184, 1//, 2013.

[27]. L. J. Cronbach, "Coefficient alpha and the internal structure of tests," Psychometrika, vol. 16, no. 3, pp. 297-334, 1951.

[28]. J. F. Hair, W. C. Black, B. J. Babin, R. E. Anderson, and R. L. Tatham, Multivariate data analysis: Prentice hall Upper Saddle River, NJ, 1998.

[29]. R. G. Netemeyer, W. O. Bearden, and S. Sharma, Scaling procedures: Issues and applications: Sage Publications, 2003. [30].G. W. Cheung, and C. Wang, "Current approaches for assessing convergent and discriminant validity with SEM:Issues and solutions." p. 12706. 
[31]. C. Fornell, and D. F. Larcker, "Evaluating structural equation models with unobservable variables and measurement error," Journal of marketing research, vol. 18, no. 1, pp. 39-50, 1981. [32].D. Hooper, J. Coughlan, and M. Mullen, "Structural equation modelling: guidelines for determining model fit. Electron $\mathbf{J}$ Bus Res Methods 6: 53-60," 2008.

[33]. R. Nadlifatin, B. Miraja, S. Persada, P. Belgiawan, A. Redi, and S.-C. Lin, "The Measurement of University Students' Intention to Use Blended Learning System through Technology Acceptance Model (TAM) and Theory of Planned Behavior (TPB) at Developed and Developing Regions: Lessons Learned from Taiwan and Indonesia," International Journal of Emerging Technologies in Learning (iJET), vol. 15, no. 9, pp. 219-230, 2020.

[34]. S. F. Persada, R. Nadlifatin, M. F. Rahman, S.-C. Lin, J. H. Munthe, and D. W. Dewi, "A Measurement of Higher Education Students' Intention in International Class Online- Learning System for Confronting the Global Education Challenge." pp. 278-283.

[35]. R. Nadlifatin, S.-C. Lin, Y. P. Rachmaniati, S. F. Persada, and M. Razif, "A pro-environmental reasoned action model for measuring citizens' intentions regarding ecolabel product usage," Sustainability, vol. 8, no. 11, pp. 1165, 2016.

[36]. J. Chin, B. C. Jiang, I. Mufidah, S. F. Persada, and B. A. Noer, "The investigation of consumers' behavior intention in using green skincare products: a pro-environmental behavior model approach," Sustainability, vol. 10, no. 11, pp. 3922, 2018.

[37]. S.-C. Lin, S. F. Persada, R. Nadlifatin, H.-Y. Tsai, and C.-H. Chu, "Exploring the influential factors of manufacturers' initial intention in applying for the green mark ecolabel in taiwan," International Journal of Precision Engineering and Manufacturing-Green Technology, vol. 2, no. 4, pp. 359-364,2015.

[38]. I. Mufidah, B. C. Jiang, S.-C. Lin, J. Chin, Y. P.
Rachmaniati, and S. F. Persada, "Understanding the Consumers' Behavior Intention in Using Green Ecolabel Product through ProEnvironmental Planned Behavior Model in Developing and Developed Regions: Lessons Learned from Taiwan and Indonesia," Sustainability, vol. 10, no. 5, pp. 1423, 2018.

[39]. B. Miraja, S. Persada, Y. Prasetyo, P. Belgiawan, and A. Redi, "Applying Protection Motivation Theory To Understand Generation Z Students Intention To Comply With Educational Software Anti Piracy Law," International Journal of Emerging Technologies in Learning (iJET), vol. 14, no. 18, pp. 39-52, 2019.

[40]. S. F. Persada, B. A. Miraja, and R. Nadlifatin, "Understanding the generation $\mathrm{Z}$ behavior on $\mathrm{D}$ learning: A Unified Theory of Acceptance and Use of Technology (UTAUT) approach," International Journal of Emerging Technologies in Learning (iJET), vol. 14, no. 05, pp. 20-33, 2019.

[41]. S.-C. Lin, R. Nadlifatin, A. R. Amna, S. F. Persada, and M. Razif, "Investigating citizen behavior intention on mandatory and voluntary pro-environmental programs through a proenvironmental planned behavior model," Sustainability, vol. 9, no. 7, pp. 1289, 2017.

[42]. S. Persada, J. Ivanovski, B. Miraja, R. Nadlifatin, I. Mufidah,J. Chin, and A. Redi, "Investigating Generation Z'Intention to Use Learners' Generated Content for Learning Activity: A Theory of Planned Behavior Approach," International Journal of Emerging Technologies in Learning (iJET), vol. 15, no. 4, pp. 179-194, 2020.

[43]. A. Al-Azawei, P. Parslow, and K. Lundqvist, "Investigating the effect of learning styles in a blended e-learning system: An extension of the technology acceptance model (TAM)," Australasian Journal of Educational Technology, vol. 33, no. 2, 2017. 